\title{
Financial and ecological compensation based on willingness to accept in sand mining of Progo River downstream
}

\author{
Rizka Widyantari* and Rika Harini \\ Geography and Environmental Science, Department of Environmental Geography, Faculty of Geography, Universitas Gadjah Mada, \\ Indonesia
}

\begin{abstract}
Sand mining which occurs massively along the Progo River causes environmental degradation and infrastructure damage. Financial and ecological compensation funds will be used to compensate for the losses suffered by the community and efforts to conserve the environment. The purpose of this research is to estimate the value of compensation to be willing to accept or willingness to accept (WTA) by the community affected by sand mining in Banaran and Poncosari villages, also the spatial variations in WTA in Banaran and Poncosari villages. We established an ecological compensation accounting system based on respondents' willingness to accept (WTA) with Contingent Valuation Method (CVM). The results shows respondents in Banaran Village has the highest average WTA value of IDR 271,142 per month. Meanwhile, the average value of WTA in Poncosari Village is IDR 186,818 per month. This value illustrates how people extremely feel disadvantaged by the degradation in the quality of the environment that occurs in their residence. WTA value obtained is influenced by the subjectivity of respondents in assessing environmental conditions and can be influenced by income and some economic characteristics. With this compensation, environmental balance is expected to be maintained without neglecting the utilization of natural resources.
\end{abstract}

\section{Introduction}

Sand mining which occurs massively along the Progo River and extends to the riverside has been exploiting natural resources. Sand mining activities have the potential to have both positive and negative impacts on the community and the environment. Sand mining activities occur exploitatively by using heavy equipment and sand extraction machines that pass permits, thus affecting the damage to the main road, shrinking well water flow, severe abrasion at the river mouth, and others [1].

The presence of massive sand exploitation will accelerate environmental damage [2]. Environmental quality degradation and various negative impacts perceived by the community due to sand mining have caused conflicts around sand mining locations, especially Banaran Village and Poncosari Village. Environmental degradation and infrastructure damage become the losses that must be borne by the community.

The condition of environmental damage and negative impacts perceived by the community need a study of willingness to accept (WTA) measurement. The research on willingness to accept analysis to estimate compensation funds for people affected by sand mining is still difficult to find. Ecosystem services and environmental costs have been considered as the basis for compensation standards in previous studies [3-5]. Many previous studies have only analyzed the impacts caused by sand mining. Some previous studies also use the WTP (willingness to pay) approach, but have not used the WTA (willingness to accept) approach. A relevant measurement when communities have rights to resources is WTA as the minimum compensation for the loss or destruction of natural resources they have [6]. This study aims to estimate the value of compensation to be willing to accept (willingness to accept) by the community affected by sand mining in Banaran and Poncosari villages, also the spatial variations in WTA in Banaran and Poncosari villages.

\section{Method}

\subsection{Study area}

The location of the study is in the Progo River downstream sand mining, Special Region of Yogyakarta specifically, in Banaran Village, Galur District, Kulon Progo Regency on the west side of the river, and Poncosari Village, Srambat District, Bantul Regency on the east side of the river (Figure 1). Banaran and Poncosari Villages were chosen to compare and analyze variations regarding the impacts of sand mining by using a spatial approach.

Sand mining at the downstream of Progo River operates in conventional or traditional ways. Some company miners use tools such as sand extractors and excavators. The sand mining company has been operating for approximately 4 years in Banaran Village. The existence of sand mining activities has caused many sand trucks to cross the road as the main access to the

* Corresponding author: rizka.widyantari@mail.ugm.ac.id 
village. The negative impacts of sand mining activities in the downstream of Progo River perceived by the surrounding community are damaged roads, dust, dried agricultural land, damaged waters, decreased carrying capacity of the river, and conflicts due to the people who are disturbed by mining activities [1].

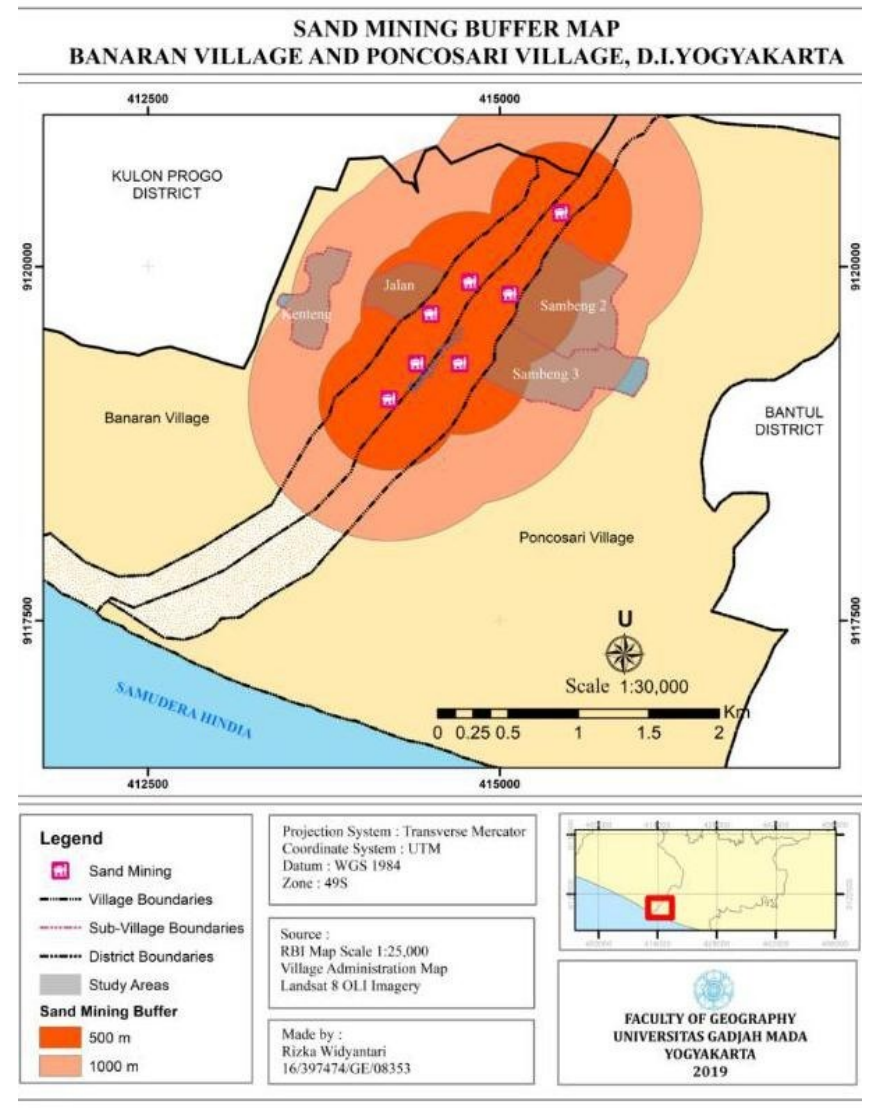

Fig. 1. Sand mining buffer map

\subsection{Sampling and data collection}

The population in this study is the community around the Progo River affected by sand mining, specifically Banaran and Poncosari Villages. Affected communities are people who live within a radius of $<1000 \mathrm{~m}$ of the mining site, so they feel the impact of sand mining activities, such as dust, environmental degradation, and so forth. The total population affected is 657 households. The calculation results on the number of samples of the Slovin method with a fault tolerance of $10 \%$ were 87 households. The sampling technique used simple random sampling based on the proportions determined by using proportional random sampling.

Table 1. Number of population and sample

\begin{tabular}{|c|c|c|c|c|}
\hline No. & Villages & $\begin{array}{l}\text { Sub- } \\
\text { villages }\end{array}$ & $\begin{array}{l}\text { Popula- } \\
\text { tion }\end{array}$ & Sample \\
\hline 1 & \multirow{2}{*}{$\begin{array}{l}\text { Banaran, } \\
\text { Kulon Progo }\end{array}$} & Kenteng & 167 & 22 \\
\hline 2 & & Jalan & 121 & 16 \\
\hline 3 & Poncosari, & Sambeng 2 & 183 & 24 \\
\hline 4 & Bantul & Sambeng 3 & 186 & 25 \\
\hline \multicolumn{3}{|c|}{ Total } & 657 & 87 \\
\hline
\end{tabular}

The research to find out compensation funds is done by collecting primary data through structured interviews with questionnaires, observations, and literature studies. The value of ecological compensation is determined based on a non-market value perspective from ecology [5]. Decisions in determining the value of ecological compensation are influenced by social welfare impact $[5,8]$. The popular method used in determining compensation value is by building hypothesis market to elicit valuations for environmental and/or public goods according to the preferences of habitants, expressed in terms of willingness to pay (WTP) or willingness to accept (WTA) [8].

Analysis of willingness to accept is known by the Contingent Valuation Method (CVM) approach. The CVM method involves building market prices in which the researcher can directly observe the correlation between economic decisions and certain non-market goods [9]. The economic value considered in the CVM represents the economic benefits/costs of certain changes in the assessed environmental goods [10].

Analysis of the willingness to accept (WTA) by the community includes the analysis of WTA willingness opportunities, the magnitude of the WTA value, and the spatial variation in WTA in Banaran and Poncosari villages. The steps to find out the value of WTA are designing and creating a hypothetical market, obtaining bids, estimating the average and/or median value of the WTA, estimating the bid/auction curve, summing the data, and evaluating the use of CVM [11]. The data are evaluated by looking at the reliability of the WTA function, the R-squares (R2) value of the multiple linear regression equation. The function of the equation is as follows:

midWTAi $=\beta 0+\beta 1$ Age $+\beta 2$ Education $+\beta 3$ Income $+\beta 4$ family dependents $+\beta 5$ environmental changes $+\beta 6$ previous compensation

\section{Result and discussions}

\subsection{Demographic}

Eighty-seven head of households were interviewed, representing two villages affected by sand mining. On average, the respondent had lived in the community in which he was surveyed for over 44 yr. The average age of survey participants is nearly 51 years of age. The average family dependents of survey participants is 3 . Forty four percent of those surveyed have completed high school. However, almost $21 \%$ of respondents indicated that they had received an elementary school education. Respondents indicated that the average personal annual income was DIR 1876758. 


\subsubsection{Analysis of willingness to accept with the contingent valuation method (CVM)}

Massive sand mining activities occur in the downstream of Progo River. The impact perceived by the community causes the need for granting compensation funds provided by mining actors. Compensation funds are provided as a form of compensation for losses and ecological compensation for the conservation of the environment affected by sand mining.

We used the CVM to develop financial and ecological compensation accounting system [5]. We adopted WTA for immediate residents to estimate ecological compensation standards for sand mining in Progo River. This approach has six stages [11]. The results of implementing the six steps of the CVM method are as follows:

\subsubsection{Building a hypothetical market}

Hypothetical market is built by providing scenarios or information to all respondents. The scenario developed is that the company and/or the actors of sand mining in the downstream will apply a policy of providing compensation funds. Compensation for direct losses was made a part of the scenario [12]. Then, in the choice sets, they were asked to accept or not accept scenarios, with various benefits accruing for accepting the risk [12]. The provision of compensation funds for environmental degradation, road damage, and other losses can disrupt the community due to sand mining operations and the activities of sand transport trucks.

The majority of respondents, amounting to $78.2 \%$, revealed that willing to accept compensation funds as a form of compensation for losses suffered was there. Almost all people in Banaran Village (92\%) were willing to accept compensation funds. It was influenced by the massive sand mining operations that operated in Banaran Village which caused losses to the community. Based on figure 2, it is known that $81.6 \%$ of the people of Banaran Village state they have suffered losses due to mining. The form of losses experienced by the community of Banaran Village is the comfort to have activities become disturbed.

Sand mining activities in Poncosari Village are still traditional and carried out by local residents [13], so that the outcome and losses perceived are not as massive as sand mining in Banaran Village. This affects the Poncosari Village community's decision to accept compensation funds (WTA). Based on the survey results, it is known that as many as $67 \%$ of the community of Poncosari Village are willing to accept compensation funds. Based on Figure 2, it is known that as many as $63 \%$ of the community of Poncosari Village state they have suffered losses due to mining. Most of the people in Poncosari Village complain that the most perceived loss due to mining is the change in the quality and quantity of water. The village of Poncosari has been experiencing a decrease in groundwater level which has affected the disruption of plants, such as coconut which are dry and not bearing fruit since mining in the west river [13].

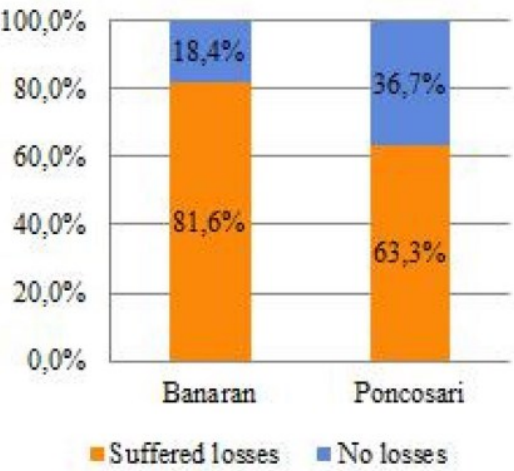

Fig. 2. Percent of the community have suffered losses due to mining

As many as $21.8 \%$ of respondents are not willing to accept compensation funds. The community does not want to receive compensation funds due to the opinion that compensation funds should be allocated for environmental conservation and joint prosperity (Figure 3). Compensation funds are better managed by relevant stakeholders, so that environmental conservation goals are better targeted. As many as $27 \%$ of people who do not want to receive compensation funds reveal a decrease in environmental quality felt that it could not be replaced with money. The community think that compensation funds are better used for environmental conservation. Meanwhile, as many as 51 $\%$ of the reasons people do not want to accept compensation funds are because they claim that they do not want to be involved in mining activities. The profits generated by mining are sufficient to be used for the village treasury and the welfare of local community traditional miners.
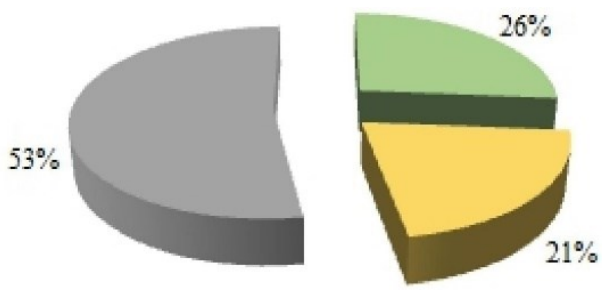

$$
\begin{aligned}
& \text { for environmental conservation } \\
& \text { for welfare of the local community } \\
& \text { they do not want to be involved in mining activities }
\end{aligned}
$$

Fig. 3. percent of the reasons people do not want to accept compensation funds

\subsubsection{Obtaining WTA value}

The value WTA was obtained from the results of direct interviews with respondents. The questions raised were based on a list of questions in the questionnaire. Interviews were conducted by using the Open-ended Question method. This method was done by asking respondents directly what the minimum amount of money they are willing to receive due to changes in environmental quality [11]. 
The Open-ended Question Method has the advantage of being able to prevent starting point bias because it does not use hints that can affect the initial value offered to respondents. The weakness of this method lies in the lack of accuracy of values and too large variations [11]. It is frequently to find respondents who have difficulty answering the questions given. The community was not given a standard upper or lower limit, so the value of the WTA mentioned was the opinion of the community regarding their impact and willingness regarding compensation funds to overcome losses received due to mining activities [14].

The respondents wanted WTA values that were quite diverse ranging from IDR 25000 to IDR 1000000 per month. The variation of the WTA value was quite high due to the use of the open question method [11]. The WTA value expected by the community has a fairly large range. This is because the differences in community opinion on the impact of the losses they receive are not proportional to the results of the profits obtained by mining activities.

The value of WTA in Banaran Village is higher than in Poncosari Village (Table 2). This is because the respondents in Banaran Village were dissatisfied with the compensation that had been going on. The maximum WTA obtained from the respondents in Banaran Village is IDR 1000000 per month per family, while in Poncosari Village; it is IDR 500000 per month. Generally, the respondents expected high compensation funds to be used as a fulfillment of rising living costs [14]. This value was considered sufficient to cover the higher cost of living [10]. The compensation fund to be received reflects the amount of the perceived loss and the willingness to accept the consequences of the negative impact caused.

Table 2. Comparison of Respondents' WTA Scores for Each

\begin{tabular}{|l|l|c|c|c|c|}
\hline Village & $\begin{array}{c}\text { House- } \\
\text { hold }\end{array}$ & $\begin{array}{c}\text { Min. } \\
\text { (IDR/ } \\
\text { month) }\end{array}$ & $\begin{array}{c}\text { Max. } \\
\text { (IDR/ } \\
\text { month) }\end{array}$ & $\begin{array}{c}\text { Average } \\
\text { (IDR/ } \\
\text { month) }\end{array}$ & $\begin{array}{c}\text { Total } \\
\text { (IDR/ } \\
\text { month) }\end{array}$ \\
\hline Banaran & 35 & 45,000 & $1,000,000$ & 271,143 & $9,490,000$ \\
\hline Poncosari & 33 & 25,000 & 500,000 & 186,818 & $6,165,000$ \\
\hline
\end{tabular}

Source: Primary Data, 2020

\subsubsection{Calculating estimated WTA average value}

The estimated WTA value of respondents was calculated based on the WTA value distribution of respondents. Based on the WTA calculation results in Banaran Village and Poncosari Village, the respondents in Banaran Village had the highest average WTA value of IDR 271142 per month. Meanwhile, the average value of WTA in Poncosari Village was IDR 186818 per month. The distribution of WTA values can be seen in the following table.
Table 3. Distribution of WTA values

\begin{tabular}{|r|r|r|r|r|}
\hline \multirow{2}{*}{$\begin{array}{c}\text { WTA } \\
\text { (IDR/ } \\
\text { month) }\end{array}$} & \multicolumn{3}{|c|}{ Frequency } & \multicolumn{1}{c|}{$\begin{array}{c}\text { Total WTA } \\
\text { (IDR/ } \\
\text { month) }\end{array}$} \\
\hline 25000 & 0 & 1 & 1 & 25000 \\
\hline 45000 & 1 & 0 & 1 & 45000 \\
\hline 50000 & 1 & 0 & 1 & 50000 \\
\hline 90000 & 1 & 1 & 2 & 180000 \\
\hline 100000 & 10 & 15 & 25 & 2500000 \\
\hline 120000 & 0 & 1 & 1 & 120000 \\
\hline 135000 & 1 & 0 & 1 & 135000 \\
\hline 150000 & 2 & 0 & 2 & 300000 \\
\hline 200000 & 5 & 0 & 5 & 1000000 \\
\hline 230000 & 4 & 0 & 4 & 920000 \\
\hline 250000 & 0 & 8 & 8 & 2000000 \\
\hline 300000 & 2 & 5 & 7 & 2100000 \\
\hline 400000 & 1 & 0 & 1 & 400000 \\
\hline 500000 & 3 & 2 & 5 & 2500000 \\
\hline 700000 & 1 & 0 & 1 & 700000 \\
\hline 750000 & 1 & 0 & 1 & 750000 \\
\hline 1000000 & 2 & 0 & 2 & 2000000 \\
\hline
\end{tabular}

Source: Primary Data, 2020

\subsubsection{Estimating bid curve}

WTA curve of respondents was formed based on the WTA value of respondents towards the desired compensation funds. This WTA curve illustrates the correlation between the desired WTA level and the number of respondents who are willing to accept at the WTA level. Based on the results of direct interviews with respondents, the WTA value can be classified into seventeen groups as described in Table 3 and produces a WTA bid curve which can be seen in Figure 4.

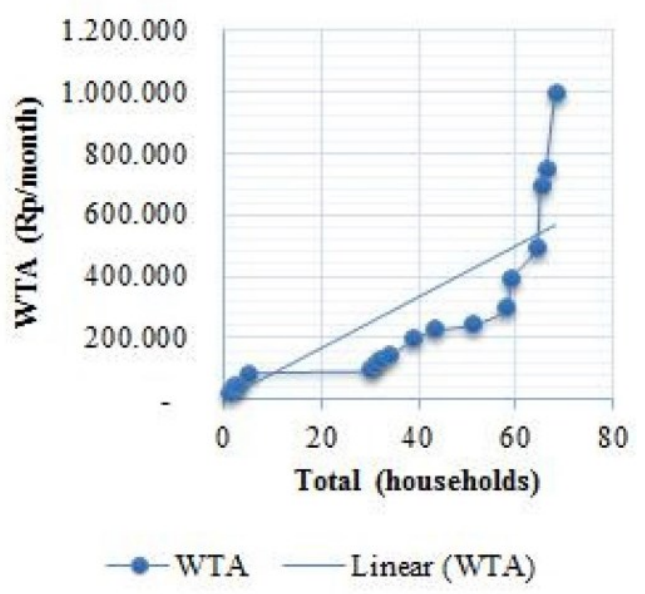

Fig. 4. Estimated WTA Bid Curve

\subsubsection{Determining the total WTA and summing the data}

Data summation is the process by which the average supply (the median bid) is converted to the intended total population. The total value of the WTA Banaran Village community is IDR 9490000 per month from the calculation of 35 heads of households. Meanwhile, the 
total value of the WTA of Poncosari Village community is IDR 6165000 per month from the calculation of 33 heads of households. This value illustrates how people extremely feel disadvantaged by the degradation in the quality of the environment that occurs in their residence. The economic values considered in CVM represent the economic benefits/costs of the particular changes in the nature of the item being valued [10].

Mining actors in Banaran and Poncosari villages have applied compensation for sand mining activities, but only given to some of the most affected communities. The total nominal obtained by the affected community in Banaran Village is IDR 45000 to IDR 200000.00 for each household, and the average compensation fund for each family is IDR 157583.00 which is given once a year. The previous form of compensation in Poncosari Village is in the form of land money for the community whose land is passed/used by a sand transport truck to the main road of Poncosari Village. The nominal received by the community who owns the land is IDR 20000 per truck that passes. Other forms of compensation are levies on income for village cash used for infrastructure improvements, such as village roads, mosques, social funds for the sick, village activities, etc

\subsubsection{Evaluation of CVM}

The research related to environmental objects can tolerate $\mathrm{R}^{2}$ values of up to $15 \%$ [11]. The results of the CVM implementation in research on this WTA are trustable and reliable. The value of R Square is 0.218 or $21.8 \%$ indicating that the independent variable affects the dependent variable by $21.8 \%$, while the remaining comes from other variables that are outside the model. The F test produces the Sig value in the ANOVA table namely 0.032 or less than 0.05 . This means that the research model is accepted and the explanatory variables in the model collectively have a significant effect on the WTA value of the respondents.

The multiple linear regression model carried out has fulfilled the classical assumptions. There are no problems with multicollinearity, autocorrelation, homoscedasticity, and normality assumption tests. The model produced by this method is:

$\mathrm{Y}=6285,444+1863,948$ Age $+7007,063$
Education
$\quad+0,027$ Income $-14976,981$ family dependents +
22497,501 environmental changes $+43041,712$
previous compensation

The CVM method can lead to some bias in the WTA survey process because of subjectivity [5]. Based on the assumption test, it is known that the value of WTA in Banaran and Poncosari villages is influenced by community income (Sig's value is 0.01 or $<0.05$ ). WTA can be influenced by personal income and preferences and some economic characteristics [5].

The CVM method involves building market prices in which the researcher can directly observe the correlation between economic decisions and certain non-market goods [9]. Respondents must be familiar with the goods and services or environmental conditions assessed/asked; therefore, hypothetical markets in the form of questionnaires and respondents must approach the actual market conditions [14].

\section{Conclusion}

Massive sand mining activities occurring in the downstream of Progo River cause environmental degradation and damage to some infrastructure. Financial and ecological compensation is important to compensate for the losses suffered by the community and environmental conservation efforts. The results of the WTA calculation use the known CVM approach that respondents expect a WTA value that is quite diverse ranging from IDR 25000 to IDR 1000000 per month. The total value of the WTA Banaran Village community is IDR 9490000 per month from the calculation of 35 heads of households. Meanwhile, the total value of the WTA of Poncosari Village community is IDR 6165000 per month from the calculation of 33 heads of households. Respondents in Banaran Village has the highest average WTA value of IDR 271,142 per month. Meanwhile, the average value of WTA in Poncosari Village is IDR 186818 per month.

The WTA value illustrates how people extremely feel disadvantaged by the degradation in the quality of the environment that occurs in their residence. WTA vallue obtained is influenced by the subjectivity of respondents in assessing environmental conditions and can be influenced by income and some economic characteristics. Mining actors in Banaran and Poncosari villages have applied compensation for sand mining activities, but only given to some of the most affected communities. Compensation funds recommendation from WTA will be used to compensate for the losses suffered by the community and efforts to conserve the environment.

The authors would like to thank for financial support by Directorate of Research Universitas Gadjah Mada through program "Rekognisi Tugas Akhir (RTA) 2020". The authors also would like to thank the Department of Environmental Geography and Faculty of Geography, Universitas Gadjah Mada.

\section{References}

1. R.D. Pramithasany, Pengaruh Penambangan Pasir Terhadap Kerusakan Lingkungan dan Sosial Ekonomi Masyarakat di Pesisir Samas Kabupaten Bantul Daerah Istimewa Yogyakarta (Studi Kasus Penambangan Pasir di Pesisir Samas Kabupaten Bantul Daerah Istimewa Yogyakarta), M.S. Thesis, Postgraduate School of Environmental Management., Universitas Gadjah Mada, Yogyakarta (2010). [in Bahasa Indonesia].

2. Suhartini, Fenomena Penambangan Pasir dan Pembangunan Beserta Dampak Lingkungan yang Ditimbulkan (Studi Kasus di Sekitar Merapi dan di Kabupaten Bantul). in Proceeding Seminar 
Nasional MIPA 2006, Yogyakarta (2006). [in Bahasa Indonesia].

3. S. Pagiola, Ecological Economics, 65,4:712724(2008).

4. L. Chunxia, X. Gaodi, X. Yu. Journal of Resources and Ecology, 3,1:20-25(2012)

5. L. Xu, B. Yu, Y. Li. Front. Environ. Sci. Eng. 9, 58-65 (2015)

6. R.T. Carson, Environmental Science \& Technology, 34,8:1413- 1418 (2000)

7. C.G. Sevilla, A.O. Jesus, G.P. Twila, P.R. Bella, G.U. Gabriel. Research Methods. Quezon City: Rex Printing Company (1993)

8. I.M. Awad, Journal of Socio-Economics 41,5:485-494 (2012)

9. R. Carson, T. Groves, Environ Resour Econ 37,1:181-210(2007)

10. X. Wang, Z. Yangyang, H. Zheng, H. Miaomiao, C. Xi. et al., Environ Earth Sci 75, 179 (2016)

11. Hanley, N., and C. L. Spash. Cost Benefit Analysis and environmental. England: Edward Elger Publishing (1993)

12. J.F. Casey, J.R. Kahn., A.A.F. Rivas. Ecological Economics, Elsevier, 67,4:552-559(2008)

13. C. Deviana, Dinamika Konflik Penambangan Pasir di Desa Poncosari, Kecamatan Srandakan, Kabupaten Bantul Tahun 2010-2015. B.S Thesis, Faculty of Social Political Science., UGM. Yogyakarta (2016) [in Bahasa Indonesia].

14. B.I. Tampubolon, Analisis Willingness to Accept Masyarakat Akibat Eksternalitas Negatif Kegiatan Penambangan Batu Gamping (Studi Kasus Desa Lulut, Kecamatan Klapanunggal, Kabupaten Bogor). B.S Thesis, Faculty of Economic and Management., IPB University. Bogor (2011) [in Bahasa Indonesia]. 